\title{
NARRATIVA DIALÓGICA DE UM CINEGRAFISTA INDÍGENA
}

- PAULINHO ECERAE KADOJEBA

Cinegrafista Bororo, Aldeia de Córrego Grande

\author{
AIVONE CARVALHO
}

Universidade Federal de Goiás

\section{- JOSÉ DA SILVA RIBEIRO}

Universidade Aberta de Portugal

No presente texto, sublinhamos o cruzamento de olhares entre os pesquisadores, no desenvolvimento de uma pesquisa participativa com o cinegrafista, em seu processo de aprendizagem e desenvolvimento do processo criativo. São itinerários que se cruzam e se apoiam reciprocamente, na pesquisa e na produção audiovisual. Se a centralidade da utilização das tecnologias do som, das imagens e a apropriação destas por Paulinho e por outros cinegrafistas indígenas são relevantes nesta narrativa, uma temática frequentemente aflora - o funeral bororo e este como um lugar de conflito com as representações televisivas e com seus atores, funcionário (Flusser) dos aparelhos. Neste sentido, a narrativa emerge como uma antropologia reciproca, em que o cinegrafista dirige seu olhar para sua comunidade, mas também para os pesquisadores e para os agentes das representações mediáticas hegemônicas, como narrativa crítica e criativa. Trata-se de uma narrativa aberta, de uma história de vida (ou de histórias de vida) aberta(s) a novas realizações e ao aprofundamento dos processos criativos e de pesquisa em ação e a seus questionamentos epistemológicos, éticos, estéticos e políticos. Minha participação (José da Silva Ribeiro) no texto resultou de uma proposta dos dois autores principais tendo como objetivo a relação entre saberes locais por eles vividos e os saberes globais que apontam para a reflexão antropológica, a criação audiovisual e a pesquisa em ação. Seguiu-se a tradição antropológica de não intervenção significativa nas narrativas dos autores principais e de colocar as questões levantadas num debate mais aberto, embora apenas iniciado neste texto.

Palavras-chave: Bororo. Cinegrafista indígena. Narrativa dialógica. Pesquisa em ação. 


\section{DIALOGIC NARRATIVE OF AN INDIGENOUS FILMMAKER}

In this text, we underline the interchanging of glances between researchers in the development of a participatory research with the cameraman in the learning and development of his creativity process. These are itineraries that cross and support each other mutually in the research and the audio-visual production. The sound and image technology is central for Paulinho, as well as other videographers indigenous, therefore, a theme emerge in this narrative - the Bororo funeral, that gives place to a conflict with television representatives, actors and technicians (Flusser). In this sense the narrative emerges as a reciprocal anthropology in which the cameraman focus is driven to his own community, together with researchers and agents of hegemonic media, as critical and creative narrative. This is an open narrative, a story of life (or life stories) open to new achievements and to the increase of creativity and research in action, and to its epistemological, ethical, aesthetic and political questions raised by this process. My participation (Jose da Silva Ribeiro) in the text was the result of a proposal from the two mains authors aiming the relationship between local knowledge, experienced by them, and the global knowledge that point to the anthropological reflection, the audio-visual creation and research in action. This was followed by the anthropological tradition of non-intervention in the narratives of the main authors and placing the issues raised in a more open debate although only started in this text.

Keywords: Bororo. Indigenous filmmaker. Dialogical narrative. Research in action.

\section{RESUMEN NARRATIVA DIALÓGICA DE UN CAMARÓGRAFO INDÍGENA}

En el presente texto subrayamos las diferentes miradas entre los investigadores, desarrollando una investigación participativa con el camarógrafo en su proceso de aprendizaje y desarrollo del proceso creativo. Son itinerarios que se cruzan y se apoyan reciprocamente en la investigación en la producción audiovisual. Se centra en la utilización de tecnologías de sonido, las imágenes y la apropiación de estas por Paulinho y por otros camarógrafos indígenas son relevantes en esta narrativa. Una temática que aflora frecuentemente - el funeral bororo y este como un lugar de conflicto con las representaciones televisivas, con sus actores y las funciones de los aparatos (Flusser). En este sentido la narrativa surge como una antropología recíproca donde el camarógrafo que dirige su mirada hacia su comu- 
nidad, hacia los investigadores y hacia las representaciones de los medios hegemónicos, como la narrativa crítica y creativa. Se trata de una narrativa abierta, de una historia de vida, (o historias de vida) abierta(s) a nuevas realizaciones y profundizaciones de los procesos creativos y de investigación en acción a sus cuestionamientos epistemológicos, éticos, estéticos y políticos. Mi participación (José da Silva Ribeiro) en el texto resultó de una propuesta de los dos autores principales, teniendo como objetivo la relación entre los saberes locales vividos por ellos y los saberes globales que apuntan a una reflexión antropológica, la creación audiovisual y la investigación en acción. Siguió la tradición antropológica de la no intervención significativa en las narrativas de los actores principales y de colocar las cuestiones relevadas en un debate más abierto, aunque apenas iniciado en este texto.

Palabras clave: Bororo. Camarógrafo indígena. Narrativa dialógica. Investigación en acción.

Sou Aivone Carvalho. Meus primeiros estudos a respeito dos Bororos foram bibliográficos. Trabalhei o aspecto narrativo do ritual fúnebre no mestrado, em Comunicação e Semiótica, na PUC de São Paulo, dissertação defendida em 1994. Em 1995, fui com minha família viver por três anos na Itália. Dediquei-me à pesquisa das coleções etnográficas bororo existentes nos museus italianos. Os trabalhos mais relevantes foram os desenvolvidos no Museo $\mathrm{Na}$ zionale Pre-historico ed Etnologico “Luigi Pigorini" de Roma, no qual realizei um trabalho de contextualização da pequena coleção ali existente, relacionando-a com os mitos e ritos.

Em 1997, iniciei um trabalho no Museu Missionário Etnológico Colle Don Bosco, em Castel Nuovo, província de Asti. Ali encontrei a maior e mais rica coleção de objetos Bororo existente fora do Brasil. Naquele momento, o Museu estava sendo reorganizado para o "Jubileu" de 2000, e fui aceita pelo grupo que desenvolvia este trabalho: uma museóloga de Gênova e uma antropóloga de Torino. Cheguei em bom momento, já que a grande parte das coleções eram provenientes do Brasil e ninguém conhe- cia muita coisa. Trabalhei na recatalogação da coleção bororo e participei do restauro higienização e acondicionamento dos objetos brasileiros, principalmente os bororos, xavantes e os das etnias do alto rio Negro.

Dos objetos Bororo trouxe a documentação fotográfica para o Brasil, com o intuito de levá-la para Meruri-MT, local onde os objetos foram coletados em 1925. Ingressei no doutorado, na PUC de São Paulo, no primeiro semestre de 1999. Meu projeto consistia em trabalhar com a documentação fotográfica dos objetos, na comunidade, na escola, uma espécie de "repatriação visual", por meio de fotografias ampliadas em xerox, quando a internet ainda caminhava timidamente.

Parti para Meruri, no segundo semestre de 1999. Quem me aceitou na aldeia foi Antônio Kanajó e Natividade, pais adotivos de Paulinho, que, mais tarde, se tornaram meus padrinhos. Meu contato com Paulinho começou ali em sua casa, onde passava horas ouvindo as histórias de Mestre Kanajó. Este contato, continuava na Escola Indígena e depois no Museu Comunitário, construído com a participação dos Bororos 
de Meruri e alguns anciões vindos de outras aldeias. Este trabalho resultou na minha tese de doutorado defendida em 2003.

Neste mesmo ano fui convidada pelo Chanceler da Universidade Católica Dom Bosco para Coordenar o Projeto de Reestruturação do velho Museu Dom Bosco, que abriu ao público em 2009, com o novo nome de Museu das Culturas Dom Bosco. Permaneci nove anos em Campo Grande e procurei desenvolver um projeto diferenciado, envolvendo grande número de indígenas de diversas etnias, cujas coleções se encontram sob a guarda daquele museu, ao que denominei "gestão compartilhada de acervos musealizados". No Museu de Campo Grande, Paulinho foi meu braço direito nos registros audiovisuais dos trabalhos ali realizados.

Paulinho por Giovanni Giuliani

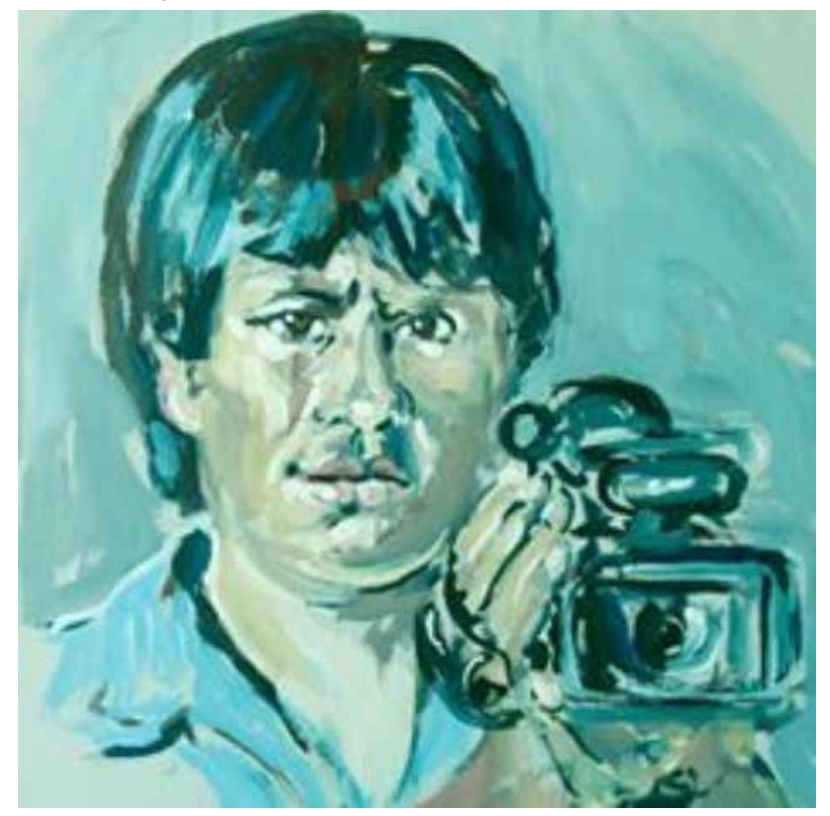

Paulinho Ecerae Kadojeba, nasceu em 7 de setembro de 1976, na aldeia de Córrego Grande, município de Santo Antônio do Leverger. É filho de Carmelita Meridoge Etuje, do clã dos Bakoro, e de Joaquim Aije Kurireu, o conhecido Joaquim Cabeça, ainda hoje chefe de canto da mesma aldeia. Paulinho é Bakoro porque os Bororos são matrilineares. Sua primazia mítica é Bakororo, o irmão mais velho da dupla de irmãos criadora das duas metades opostas e reciprocas, as Ecerae e Tugaregue. Heróis também legisladores e moderadores dos Bororos, em tempos primevos, ao morrerem, a dupla de irmãos deu origem ao reino dos mortos, no sol nascente e no sol poente, reciprocamente leste e oeste, para onde vão todos os Bororos que passam pelo extenso ciclo fúnebre. Morador do oeste, Bakororo e Paulinho são mitos de um mesmo clã, o dos fortes e pesadões, o daqueles que chegam para ensinar.

Dona Carmelita, porém, morre quando Paulinho é ainda menino e ele então é criado por Antônio Kanajó e Natividade, sua avó de sangue. Grandes conhecedores da cultura foram colaboradores de um grande número de intelectuais que estudaram a cultura bororo, para quem deram belos nomes de sua primazia clânica, os Bokodóri

Pouco mais tarde, Natividade quis voltar com a família para Meruri, sua aldeia de origem, e Antônio Kanajó os acompanhou. Paulinho chegou a Meruri com os pais adotivos, onde foi criado. Dono de uma sensibilidade ímpar, aprendeu música, fotografia e a operar uma câmara filmadora.

Do início de sua vida em Meruri, Paulinho contou, mais tarde, um pequeno episódio ao iniciar sua fala em um curso de vídeo para realizadores indígenas em que foi professor, no Museu das Culturas Dom Bosco, para ilustrar conceitos que inaugurariam uma nova era para os povos indígenas: a dos textos contados por meio de imagens dinâmicas e a sua importância para preservar aspectos importantes das culturas indígenas.

Quando comecei ir pra Escola em Meruri, me aconteceu uma coisa muito interessante, vocês vão rir de mim, mas não tem importância não, o importante é entendê aquilo que eu quero passá pra vocês. Então... lá na Escola da minha aldeia, todo dia batia o sino e tinha merenda. Tinha aprendido com minha vó que tudo que nós ganhasse para comê, tinha que levá um pouquinho para casa. Nesse dia o sino bateu e 
a molecada tudo correu. A merenda tava sendo repartida e era uma coisa muito gostosa, o tal picolé que eu nunca tinha visto. Cada um ganhou dois. Eu chupei um e guardei o outro para levar para minha avó. Guardei ali, logo atrás da Escola, em cima de um toco mais escondido da cerca. Não tive sossego no resto da aula, pensando na alegria de minha vó quando fosse comê aquele docinho frio. Quando a aula terminou, corri pra pegá o presente, mas quando cheguei lá só tinha um palito vazio, alguém tinha comido o meu doce. Chorei de raiva. Se pegasse o ladrão, ia ter briga!

Por isto pessoal, não adianta chorá nem querê brigá por aquilo que, por nossa inocência, foi perdido. Hoje vamo aprendê uma outra forma de congelá, uma forma que não derrete, que não fica só o palito, o osso. Vamo aprendê a congelá as imagem e nada mais vai derretê das nossa tradição, das nossa cultura. De agora em diante, nada mais será perdido ou levado pra satisfazê os intelecto dos outro, porque a gente vai sabê de tudinho quando eles chegá tirando foto ou filmando nós.

\section{Estabelecendo laços}

A partir de 1999, na aldeia de Meruri, em Mato Grosso, região central do Brasil, desenvolvi um projeto de pesquisa para testar o potencial da documentação fotográfica da coleção bororo existente no Museo Missionario Etnologico Colle Don Bosco - Itália, quando colocada em contato com os remanescentes Bororos da região em que os objetos foram coletados, na primeira metade do século passado. 0 resultado foi o surgimento de um Centro de Pesquisa e Valorização da Cultura Bororo, hoje denominado Museu Comunitário Bororo e Centro de Cultura Pe. Rodolfo Lunkenbein, ${ }^{2}$ com a participação de grande parte da comunidade.

O primeiro passo foi conhecer as pessoas e estabelecer laços de confiança mútua para dar

1 A pesquisa foi iniciada na Itália no ano de1997, ano em que trabalhei como pesquisadora neste Museu.

2 Padre Rodolfo Lunkenbein era um missionário alemão, assassinado em Meruri, em um conflito com fazendeiros, na defesa das terras bororo. seguimento à pesquisa. Dessa forma, em conversa com um grupo de estudantes da Escola Indígena de Meruri, ${ }^{3}$ percebi que eles queriam discutir o fato de que sua cultura estava entre uma das mais estudadas do mundo e que, apesar disso, o acervo de pesquisas realizadas na própria aldeia de Meruri serviu apenas para dar títulos acadêmicos aos não índios, enriquecendo as teorias antropológicas e as bibliotecas das Universidades, e que nada retornou a Meruri para o enriquecimento intelectual deles próprios.

Sobre o assunto, comentou Felix Rondon Adugo Enawu, hoje Secretário da Educação Indígena no Estado de Mato Grosso:

[...] a gente não tem conhecimento de muita coisa que foi registrada sobre nosso povo. Esse material sempre serviu para enriquecer o conhecimento dos brancos. Nós queremos conhecer melhor a nossa história. Por isso é importante a gente pedir aos pesquisadores que façam a doação de uma cópia de seus trabalhos para nós. Apesar de que é uma coisa nossa mesmo, mas a gente vai pedir com todo o respeito.

Sobre o assunto, acrescentou Paulinho:

É, nós temos de dá valor àquilo que temos, àquilo que somos, porque temos nossos costume, nossas dança, nossas linguagem, tudo isto são nossos documento que foi levado de nós, e cadê? Ninguém conhece nada, ninguém sabe de nada!

O segundo passo foi a apresentação da documentação fotográfica e a descoberta por parte do mesmo grupo de que o acervo cultural bororo se encontra em alguns museus na Europa e é exposto sem o cuidado necessário com a sua significação, ${ }^{4}$ permanecendo

3 Neste ano, um grupo de rapazes e moças se preparava para o vestibular na Universidade Indígena, em Barra do Bugres-MT. Uma parte do grupo já era professor na Escola Indígena de Meruri.

4 Os objetos da cultura material bororo, em sua maioria, são rituais e fora deste contexto perdem seu verdadeiro significado, como, por exemplo, o objeto powari aroe, exposto, na época, no antigo Musée de l'Homme em Paris, com a simples indicação 
ali como objetos deslocados de uma cultura enfraquecida.

Tal como Berta Ribeiro (1983, p. 108), que propôs uma nova estética para as novas formas de reelaboração do sistema dos objetos étnicos, fomos desenvolvendo, conjuntamente, um mecanismo de atuação, na própria Escola, com o objetivo claro de inserir as fotografias dos objetos no projeto didático dos professores de todas as séries, naquele mês. Depois do estudo bibliográfico, as fotografias foram apresentadas aos alunos. A escolha foi feita respeitando os grupos de objetos pertencentes a cada ritual para a produção de textos escritos ou visuais (desenhos), em todas as salas. As crianças podiam levar para casa a fotografia do objeto que desejavam trabalhar, procurar os mais velhos e depois trazer as informações para serem discutidas em grupo. Depois, partiriam para a produção de textos em forma de cartaz. 0 resultado foi tão surpreendente que, no final desta primeira etapa, em que trabalhamos o grupo de objetos que fazia parte do rito de nominação, os objetos foram reconstruídos de forma concreta e duas crianças foram nominadas com grande festa.

A partir de então, tornou-se evidente que a criação de um Museu Comunitário seria o próximo passo que levaria a pesquisa adiante, já que aqueles objetos reconstruídos com muita dificuldade, por falta de matéria-prima, precisavam ser preservados. A ideia foi discutida com os professores, alunos e algumas pessoas da comunidade e em pouco tempo tínhamos

\footnotetext{
"clarineta". O objeto é um dos mais sagrados da cultura bororo. É um instrumento de sopro construído durante os funerais de um morto e serve para chamar a sua alma, durante o funeral, em um dos momentos mais solenes, quando the oferecem água doce e cigarros. Depois disto, é guardado na casa da família enlutada, como o representante material do falecido e cada vez que acontece um funeral é novamente utilizado para, com seu som particular, chamar o seu dono a participar do mesmo banquete. Anos depois, exatamente o mesmo objeto foi transferido para o moderníssimo Musée du Quay Branly, com o mesmo erro contextual.
}

o Museu, ${ }^{5}$ com sala de "expressão de cultura", sala para a projeção de vídeos, biblioteca, o primeiro laboratório de computação, arquivo e sala de aula. A intenção era preencher todos esses espaços com trabalhos dos próprios indígenas, entretanto, um deles, o arquivo, deveria ser iniciado com as obras dos pesquisadores da cultura bororo, que seriam reivindicadas pelos Bororos da Escola Indígena.

Gonçalo Ochoa, Mario Bordignon, salesianos que pesquisaram a cultura durante quase uma vida, e a antropóloga Renate Viertler foram os primeiros a compreender a ideia e a entregar, pessoalmente, toda sua obra aos Bororos, em Meruri. Grande parte dos volumes da Enciclopédia Bororo ${ }^{7}$ que ficavam na Biblioteca da Universidade Católica Dom Bosco, em Campo Grande, foram transferidos para a biblioteca do pequeno museu.

Paulinho Ecerae Kadojeba e seu avô, Antônio Kanajó, foram fundamentais na construção dos espaços, inclusive na Sala de Expressão de Cultura, onde construímos uma museografia retratando a aldeia, na sua forma tradicional, com os oito clãs e as duas metades. Os clãs representados pela fachada de pequenas casas bororo, em palha trançada, formaram as vitrines clânicas. Uma outra vitrine, de forma octogonal, em madeira e vidro, foi construída com

5 Uma garagem velha pertencente ao complexo da Missão Salesiana foi doada e o financiamento foi buscado junto à Procura Missionária Italiana de Torino, instituição salesiana de coleta de fundos para financiar projetos em muitos lugares no mundo. Havia conhecido seu fundador e presidente, na época em que trabalhei no Museu Missionário Etnológico Colle Don Bosco. Era simpatizante de meu projeto com os Bororo e não foi difícil conseguir convencê-lo de sua importância

6 Os Bororo preferiram o nome "sala de expressão de cultura" porque o nome "exposição", naquele momento, tinha para eles um significado associado ao verbo cuja ação reflete ao próprio sujeito, ou seja, expor-se

7 A Enciclopédia Bororo é de autoria de Cesar Albistti e Angelo Venturelli, com a colaboração de Tiago Aipobureu. A obra é composta de 4 volumes que descrevem com riqueza de detalhes a cultura deste povo nos seus aspectos cosmogônicos, religiosos, artísticos, mitológicos, rituais e suas relações com o mundo material por meio de seus artesanais. 
um grande mastro no centro, representando a "casa central", ${ }^{8}$ para abrigar uma pequena coleção repatriada ${ }^{9}$ do museu italiano. As duas formas de repatriação, a visual e a concreta, foram o estímulo maior para o início das oficinas que começaram a acontecer. As oficinas foram lideradas por Kadojeba, Leonida Akiri e Agostinho Eibajiwu, voluntários para as etapas seguintes.

A partir daí, inauguramos um ciclo de várias oficinas, ${ }^{10}$ desta vez, selecionando os objetos pela sua tipologia porque, devido à escassez de matéria-prima, tínhamos que aproveitar o tempo segundo o material que conseguíamos. Assim, enquanto tentávamos conseguir o material para a oficina de plumária, trabalhávamos com o algodão, muito mais fácil de obter.

Passo a passo, as oficinas foram recriando a coleção,11 em um clima de alegria e contentamento. A cada objeto refeito, muitas histórias brotavam e iam ressignificando o patrimônio tangivel e intangivel da cultura bororo, por que cada objeto, bem como a matéria-prima de que é composto estão intimamente ligados ao seu mundo mítico ritual. Procuramos fazer essa ligação com a ajuda de anciãos da aldeia de Meruri e de outras aldeias, e da Enciclopédia Bororo (1962), de César Albisetti e Angelo Jayme Venturelli.

8 As aldeias bororos são circulares, divididas em duas metades com uma casa de forma retangular no centro. Esta casa também pode ser chamada de casa dos homens.

9 Conseguimos repatriar 14 objetos do Museu do Colle para o Museu Comunitário de Meruri. Foram entregues no dia de sua inauguração, em 15 de julho de 2001.

10 As oficinas realizadas neste primeiro ciclo foram: tecelagem em algodão, trançados em palha, plumária, arco e flecha, chocalho (construção e manuseio), canto, borduna, madrepérola, peitorais, pregos para cabelo e outras.

11 A coleção da cultura material bororo do Museu Missionário Etnológico Colle Dom Bosco é a mais numerosa e diversificada do mundo. Data de 1925, quando o Papa convocou missionários de todo mundo para uma grande coleta e o envio de material para a Itália, com o objetivo de realizar uma grande exposição nas comemorações do Jubileu de 1925. Depois da exposição, parte dos objetos bororo foi para o Museu Etnológico do Vaticano e cerca de 600 objetos para o Museu do Colle.
Construímos um museu no qual a comunidade pode utilizar os objetos. Qualquer objeto pode ser retirado e usado pelos seus possuidores clânicos ${ }^{12}$ e depois devolvido para que seja curado e assim tenha uma vida longa. Infelizmente, hoje não há matéria-prima ${ }^{13}$ em abundância. O desmatamento para a plantação de soja ou para as pastagens está acabando com a fauna de Mato Grosso. Os Bororos sempre se preocuparam em preservar a natureza, mas o entorno de suas terras já foi todo devastado.

As oficinas de revitalização da técnica reuniram jovens velhos e crianças munidos de um mesmo entusiasmo que parecia lhes devolver muito mais do que a técnica de construção de sua cultura material, mas a riqueza perdida a partir do momento em que foram assimiladas as necessidades materiais de outra cultura. De fato, cada um que ainda podia reconhecer ou que reaprendia a conhecer as insígnias de seu clã de origem, estampadas nos objetos, exclamava orgulhoso: "este é meu; este é meu!"

Cada trabalho de campo era fotografado e filmado. Assim, todos os Bororos que desejavam tinham acesso aos equipamentos, vistos apenas nas mãos de visitantes ou pesquisadores com metodologias mais tradicionais. Paulinho, depois de um tempo, já operava a câmera fotográfica e a filmadora, com facilidade, tomava conta das filmagens e dos equipamentos. Entretanto, foi preciso realizar uma oficina de fotografia e de vídeo, para que moças, rapazes e crianças pudessem aprender a registrar imagens, coisa que Paulinho havia aprendido qua-

12 Claude Lévi-Strauss (1986, p. 219), ao estudar os Bororo, na primeira metade do século XX, já havia observado que a riqueza estatutária dos clãs é diferente da nossa. "Cada clã possui um capital de mitos, de tradições, de danças, de funções sociais e religiosas. Por sua vez os mitos fundam privilégios técnicos [...] que consistem na utilização de certas plumas ou cores de plumas, na maneira de talhar e chanfrar, na disposição de plumas de espécies e cores diferentes, na execução de certos trabalhos decorativos...

13 Nas oficinas, utilizamos matéria-prima conseguida por meio de permuta com outras etnias, como os Rikbaktsa, Xavante e outros. 
se que sozinho. Essas oficinas foram realizadas em 2002, época em que os equipamentos ainda não eram digitais e em que as imagens fotográficas eram reveladas por meio de processos químicos. Paulinho, ao mesmo tempo que fazia a oficina, trabalhava como assistente de Sérgio Sato, um de meus alunos do curso de Publicidade e Propaganda, voluntário para ministrar a oficina.

Acatando então a nova exigência que se apresentava, o Museu Comunitário Bororo de Meruri ofereceu à comunidade ${ }^{14}$ a possibilidade de imersão em um contexto tecnológico que ia se renovando à medida que novas tecnologias iam surgindo. Toda essa estrutura material foi explorada ao máximo, principalmente por Paulinho, e a produção de imagens autorrepresentativas tornou-se prática exercida habitualmente, tanto que o arquivo do $\mathrm{Mu}$ seu, depois de alguns anos, conseguiu reunir uma infinidade de fotografias e uma centena de horas de gravação nos formatos VHS e DV.

\section{Outros tempos vieram}

A primeira preocupação dos salesianos, depois do contato com os Bororos, em 1898, na região dos Tachos, vizinha a Meruri, foi a educação. Assim, desde o início, tentaram transformar uma sociedade oralizada em alfabética. Cunharam a Língua Bororo, alfabetizaram em língua estrangeira, a Portuguesa, e registraram nas duas línguas tudo o que conseguiram, nestes mais de um século de convivência. Pode-se dizer que existiram e existem bororos cultos, como Tiago Aipobureu, colaborador da Enciclopédia Bororo que, tendo vivido algum tempo na Europa, falava várias línguas, ou atualmente Felix Rondon, mestre em Educação e Secretário da

14 Os equipamentos eram financiados pelo PROARI (Programa de Apoio aos Realizadores Indígenas), criado durante o Projeto de Reestruturação do Museu Dom Bosco/Universidade Católica Dom Bosco, coordenado por mim. A verba para todos os projetos vinha da Procura Missionária Italiana sediada em Torino - IT.
Educação Indígena do Mato Grosso, dentre outros. Pode-se dizer que todos em Meruri, com exceção das crianças muito pequenas, leem e escrevem.

Independente dos motivos que transformaram a sociedade bororo de Meruri em alfabética, esta condição só minimiza a distância para com uma ferramenta capaz de redigir um texto composto de oralidade e iconografia, de maneira que as duas formas de expressão não são excludentes, mas complementares e podem, juntas, desenvolver reflexões sobre a operatividade da cultura e materializar um discurso de autoria de quem viveu e vive a experiência. Contudo, não se pode apagar do universo bororo o imaginário próprio da oralidade.

Quando um Bororo assiste a um documentário contendo sua imagem, fica fascinado, mas também fica decepcionado quando constata que o evento, apresentado em sua totalidade, sofre cortes que, na maioria das vezes, omitem cenas para eles relevantes na interpretação de sua cultura pelo outro ou quando revelam momentos sagrados e secretos para a manutenção da ordem social bororo, causando desequilíbrios à comunidade.

Ver sua imagem na televisão ou por outras mídias como DVDs e afins é uma conquista passiva porque o torna, intrinsecamente, parceiro do detentor do poder dos brancos. Em igual intensidade essa parceria é suficiente para colocar os envolvidos em posição delicada na sua comunidade, porque lhes confere a responsabilidade pelo desequilíbrio causado pela exibição sem censura de seus segredos.

No caso das produções videográficas desenvolvidas por Paulinho na comunidade de Meruri não é diferente. Seu compromisso, assumido e imposto pela sua comunidade, não é mostrar neste ou naquele meio de comunicação o exotismo da cultura bororo. Seu protagonismo tem relevância no registro das práticas 
culturais e cotidianas de seu povo, utilizando uma linguagem visual e sonora que seu povo compreenda e possa se sentir bem em participar. Despretensiosamente, a produção de Paulinho desperta interesse pelos não índios, mas o que ele sempre alegou como objetivo é registrar para não perder; mostrar para o orgulho da sua gente e exercitar um dom único para ele: o de mostrar como seus olhos veem e reconstroem a realidade.

Não foi fácil, porém, chegar até aqui, mas houve muito esforço da parte de Paulinho, sendo o episódio mais marcante deste aprendizado aquele que envolveu a FUNAl, a Rede Globo e uma jornalista brasileira, segundo ela, ligada à UNESCO, que apareceram em Meruri, para o funeral do senhor Macielzinho, realizado na Aldeia do rio Garças, dentro da mesma reserva indigena. Chegaram ali com os equipamentos e Paulinho, obviamente, se interessou. Combinaram que ele os ajudaria acompanhando-os nas diversas fases do ritual, uma situação muito cômoda para eles, pois assim teriam acesso ao todo do rito, ou seja, estavam com um Bororo, estavam em casa. Em troca, eles lhe ofereceram um curso de "cinegrafista" na Rede Globo e ele acreditou. Esta parte, o próprio Paulinho vai narrar.

\section{A reação do tempo (Paulinho)}

Foi em 14 de agosto, em uma quinta-feira, por volta das 20:00 h, do ano de 2003, que chegou em Meruri a equipe da TV Centro América/ Cuiabá-MT, da Rede Globo, com uma jornalista chamada Maria Luíza, que dizia estar apoiada pela UNESCO e pela FUNAI, para fazer a filmagem de um ritual funerário sagrado e respeitado pelo nosso povo bororo.

Aproximei-me deles e me apresentei com todo respeito, ai eles me chamaram para fazer companhia pra eles, durante a filmagem do funeral. 0 morto era o Sr. Maciel Paiwoe Ekudugodu. Eles se hospedaram na Missão Salesiana e, no dia seguinte, às 13:30 $\mathrm{h}$ fomos pra a Aldeia do rio Garças, onde ia acontecer o funeral. Esse ritual acontece no final do ciclo fúnebre e dura três dias, desde sexta-feira até o domingo, lá pelas 17:00 $\mathrm{h}$.

Na verdade, eu estava ali para ser guia da equipe, principalmente nas muitas fases do detalhado funeral, porque existem partes desses rituais que mulheres e crianças não iniciadas não podem participar ou ver, mas somente os homens e as crianças que já foram iniciadas podem participar e ver.

Eu achei que a TV Centro América tinha sido chamada pela professora Aivone Carvalho, que sempre estava dando apoio para a gente retomar nossa cultura. Eu sempre apoiava ela e ela me apoiava nos registros de todas funções que aconteciam em Meruri ou na Aldeia do rio Garças. Nessa época, os Bororos já tinham seu Museu, que tinha um arquivo para a gente juntar nossos registros.

Mais tarde, eu assustei porque chegou a professora Aivone com alguns de seus alunos. O cinegrafista da TV Centro América, Valdeci Queiroz, perguntou-me quem eram aquelas pessoas. Achei estranha a pergunta, mas respondi explicando sobre nosso projeto junto com a professora no Museu e no nosso arquivo. Em seguida, fui receber a professora Aivone que me fez a mesma pergunta. Só então percebi que se tratavam de coisas diferentes.

A jornalista Maria Luiza percebeu que comecei a não me sentir à vontade, porque não sabia direito quem eram eles e começou a me agradar, dizendo que, se eu ajudasse eles, ela colocaria meu nome junto com os créditos da equipe dela. Mas nem era crédito que eu queria, a vontade de aprender mais é que estava falando mais alto. Aquela gente ali era profissional! Eu já tinha noção de operar uma câmara porque aprendi nos cursos que a professora Aivone dava para nós com seus alunos. Mas eu só tinha máquina de fotografia e aquela câme- 
ra ali era profissional, eu estava fascinado com aquilo. Na verdade, era minha curiosidade que estava me movendo ali, apesar da curiosidade não ser muito aconselhável, pensei que podia ser útil naquele caso.

Aconteceu que teve uma hora em que o assistente do cinegrafista, o Argel, tinha esquecido uma bateria da câmera e foi buscar e o cinegrafista Valdeci Queiroz precisava de alguém para fazer iluminação porque, a qualquer momento, poderia acontecer um dos movimentos importantes do funeral e ele não queria perder. A jornalista, certamente, poderia fazer isto, mas como é que ela conseguiria ficar com o microfone na mão e iluminar ao mesmo tempo? Foi quando Valdeci me pediu pra fazer a iluminação. 0 cinegrafista ficou surpreso, não imaginava que eu podia fazer uma iluminação tão perfeita. É verdade que minha altura ali ajudou, mas era justo também que eu sabia mesmo como fazer, para não provocar sombra. Depois disso me elogiaram muito e eu fiquei acreditando que alguma coisa na minha vida poderia mudar na profissão que eu queria para mim. Pouco mais tarde, foi o cinegrafista que teve de sair e me pediu para cuidar da câmera, antes de ir me ensinou como é que tinha de fazer, no caso de acontecer alguma coisa do funeral que precisasse ser filmada. De fato, aconteceu de eu ter de filmar a dança do aroe maiwu ${ }^{15}$ no pátio da aldeia.

Ali estava claro que havia conseguido a confiança da equipe. Foi aí que escutei eles falando que não sabiam que existiam índios inteligentes, capazes de trabalhar com câmera de filmar. Então, eles me perguntaram se eu queria fazer um curso de cinegrafista lá na Rede Globo. Eu disse que sim, e fiquei muito animado, porque eles me falaram que minha visão através da câmera era perfeita. Compa-

15 Aroe Maiwu é o representante da alma do morto que se enfeita e, depois de incorporar sua alma, sai dançando pelo pátio. Depois tem a iniciação dos meninos e a queima dos pertences do morto. rando a minha iluminação com a do Argel, eles disseram que a minha estava muito melhor

A partir daí, era Paulinho pra lá, era Paulinho para cá, eles começaram a aproveitar dos meus conhecimentos, do meu trabalho como assistente da equipe. Argel, que era assistente oficial da equipe, ficou mais para cuidar da recarga das baterias e eu, além de tudo, fazia a tradução e abria as portas para a filmagem de tudo. Pensei que estava fazendo um bem.

Pelo que eu percebi, tinha duas pessoas da FUNAI junto com a equipe, uma de Barra do Garças, que não me lembro o nome, e outra pessoa, um tal de Jonas, um fotógrafo de Brasília. Todos eles, praticamente, prometeram me dar curso de filmagem, inclusive, o cinegrafista Valdeci me disse que seria ele mesmo a me treinar, e que eu poderia ficar em sua própria casa. De vez em quando, a professora Aivone chegava perto de mim e pedia para eu ter cuidado com aquele grupo. Eu bem que percebi que, ao ser entrevistada pela equipe, mentiu sobre o significado dos Aije, ela estava desconfiada, mais do que eu.

De fato, um documentário sobre o ritual do Sr. Macielzinho foi ao ar no mesmo agosto de 2003, no dia 3, no programa Fantático da TV Globo. 0 título era: "Sepultamento da tribo bororo é uma janela para a pré-história", tendo Maria Luíza Silveira como autora do roteiro e da edição. Levaram ao ar e publicaram no site do programa, com 2.674 perguntas no chat, após a apresentação. Não sei se souberam responder àquelas perguntas sobre uma cultura que não conheciam, sobre um documentário que, além de mentiroso, mostrou tudo aquilo que, para eles era "fantástico" e que, para nós, era sagrado.

Fiquei mesmo perto do Valdeci e informei a ele para não gravar certas coisas, mas mesmo assim as coisas que não eram para gravar foram gravadas e todas as imagens foram exibidas no Fantástico. Os anciãos ficaram muito

16 Aije é um de nossos segredos. 
indignados comigo, por ter ajudado a filmar as imagens proibidas. Isto não foi culpa minha e não foi por falta de passar a informação certa para a equipe, mas os anciões acharam que fui eu quem autorizou a passar as imagens proibidas no Fantástico.

Quando o funeral terminou, eles me deram cinquenta reais, quase uma esmola. Hoje, eu vejo que isso foi absurdo. Tinha gente da FUNAI lá. O tal fotógrafo Jonas, ele poderia me orientar diante desse pagamento ridículo e ofensivo, mas ele deixou isso passar. Minha conduta ficou suja na visão dos nossos anciãos e me senti humilhado.

Fiquei mal diante da minha comunidade e diante de cada Bororo, vivo ou morto. Eu havia ajudado a revelar nossos segredos, acreditando que eles nunca iam fazer isto. Eu disse a eles o que podia ser mostrado e o que não podia, mas eles não escutaram. Caí que nem um patinho! Chorei demais de vergonha. Prometi a mim mesmo que ia aprender a fazer documentário e que daria à minha comunidade um documentário sobre o funeral, diferente daquele, com as partes que só homem pode ver e com partes próprias só para as mulheres.

Ninguém recebeu nada que qualquer um do grupo tenha prometido. 0 finado José Carlos, cacique e chefe de canto da aldeia, chegou a ir em Cuiabá atrás deles, mas todos tinham desaparecido. Nunca ninguém apareceu para me dar curso algum. Até o fotógrafo Jonas, de Brasília, que havia me pedido meus áudios de cantos bororo, que estava fazendo ao mesmo tempo em que ajudava a equipe de filmagem, não cumpriu o que prometeu. Ele pediu minhas fitas gravadas para fazer um CD, dizendo que iria devolver e me mandar um $C D$ com capa e tudo, e que eu ia gostar. Certo, ele ainda foi legal de me devolver minhas fitas, mas o $C D$, estou esperando até hoje.

Só dois anos depois tive minha primeira câmera filmadora. A profa. Aivone ganhou na
Itália e trouxe para mim. Veio para a aldeia de Meruri e me fez uma surpresa... para mim e para nosso Museu. Era uma câmera digital mini DV, era mesmo um presente para meu trabalho! Todos os que estavam perto de mim ficaram felizes de ver uma câmera daquelas. Fiquei até sem jeito e não disse nada, apenas sorri e olhei para o equipamento pensando que aquilo ali era muito para mim, logo eu, justamente eu! Fiquei contente, mas desconfiado e com medo dos velhos, de não deixarem eu filmar o funeral que estava prestes a acontecer, inclusive era da esposa do próprio finado José Carlos, ancião Meriri Ekureu, também enganado pela Rede Globo.

Com calma, sabedoria, conhecimento e amizade, a profa. foi até a Aldeia do rio Garças comigo, para pedir permissão ao Sr. José Carlos para fazer a filmagem do funeral da sua esposa; era uma conversa muito dificil, não era qualquer pessoa que podia convencer o velho. $\mathrm{Na}$ verdade, fui eu a primeira pessoa a ser convencida a registrar o funeral de dona Mariona, porque eu estava com muito medo e vergonha. Para mim, era um recomeço diante de minha comunidade. Depois disto, fui me programando, pensando em um roteiro que pudesse agradar a minha gente, e me perguntava como seria quando chegasse ali com minha própria câmera. E já animado e decidido, comecei a imaginar muitas coisas a respeito das imagens que ia fazer.

Quando chegou a época dos três últimos dias do funeral, comecei a trabalhar em pensamento. Para me ajudar nesse funeral, a profa. Aivone e Sérgio Sato trouxeram um cinegrafista de São Paulo, o Albert. Ele ia me ajudar na retomada de meu caminho. Aí foram mais coisas que aprendi sobre a câmera filmadora, aprendi a bater o branco para fazer a câmera reconhecer a entrada das luzes, não usar bastante o zoom etc... e fomos trabalhando juntos. Ele me filmava também enquanto eu estava filmando. 
Nas imagens éramos três: eu, na câmera filmadora, Albert também e o Sérgio na câmera de fotografia. A professora fazia a descrição, vendo cada detalhe, inclusive com o nome das pessoas e tudo o mais. Tinha, às vezes, a impressão de que minha presença com a câmera na mão incomodava as pessoas, imaginava que eles deviam estar lembrando da minha participação junto à equipe da TV Centro América/ Rede Globo, em 2003. Ficava imaginando que aquelas pessoas não estavam confiando em mim, mas a professora, ao mesmo tempo que me encorajava, também me defendia, dizia a eles que eles estavam sendo injustos comigo e que, principalmente, tinha sido enganado. Então, eu superei, fazendo de conta que não via e não ouvia nada. Para mim, tudo estava certo e estava mesmo porque a equipe que eu estava, naquele momento, queria meu crescimento e não minha derrota. Por isso, me senti seguro durante o trabalho e durante o funeral.

O trabalho era intenso e cansativo, todos os que participaram pesquisando, filmando e fotografando, sentiram isto. Para pegar maiores detalhes do funeral, é preciso suar porque as fases são longas e ininterruptas. Tivemos um momento de intervalo, nós que estávamos trabalhando nos reunimos com a professora Aivone. Foi quando ela me perguntou se estava gostando do trabalho e respondi que sim, ela estava feliz em me ver em outra situação. Nesse tempo, ela estava em Campo Grande, trabalhando para fazer o museu de lá - Museu das Culturas Dom Bosco e tinha organizado um projeto: o Programa Apoio aos Realizadores Indígenas, que estava começando ali comigo, naquela horinha, ela disse. Então ela me perguntou se eu queria, eu mesmo, fazer a edição do meu próprio documentário, em Campo Grande, lá no Museu. Eu respondi, quase emocionado, que sim. Aquela filmagem ali teria o desfecho do meu sonho, em me retratar com minha comunidade, mostrando que era pos- sivel fazer um documentário que não ferisse nossos segredos.

Assim, depois de alguns dias, passamos para outra etapa do meu aprendizado. Fiquei bastante tempo trabalhando na decupagem das minhas próprias imagens. Visitei e conheci o estúdio de produção de audiovisual da Universidade Católica Dom Bosco. Fiquei ali um dia inteiro com Sérgio, só pra ter uma ideia, mas como esse estúdio era também um laboratório de produção de propaganda, ficou muito dificil prosseguir. Foram muitas viagens a Campo Grande, porque não podia ficar lá por muito tempo. Trabalhava como agente de saneamento básico na minha aldeia e não podia me ausentar por muito tempo. Às vezes, para sair, tinha de pagar um colega para ficar em meu lugar, para não me indispor novamente com minha comunidade.

O documentário estava quase pronto, mas faltava ainda algumas coisas que não encontrava solução. Nem a professora nem o Sérgio queriam interferência nos meus pensamentos e eu sozinho não estava conseguindo levar adiante. Aí a professra teve a ideia de chamar para me ajudar um cinegrafista indígena xavante, o Divino Tserewahu, da aldeia de Sangradouro, que tinha saído do Projeto Vídeo nas Aldeias, de Vancent Carelli. Precisava, porém, da minha permissão, então permiti que a ideia dela acontecesse.

Foi uma ideia certeira, porque foi com ele que finalizei meu vídeo e que aprendi muitas coisas que os brancos não sabem. Descobri que Divino era um dos grandes conhecedores das imagens realizadas por indígenas, e conseguiu várias premiações por causa de seus vídeos sobre a cultura xavante. Incrivel que, durante a edição do meu documentário, Divino reconheceu as imagens do ritual e lembrou das imagens de funeral bororo que foi transmitido pelo Fantástico/Rede Globo e teve a ideia de usar algumas imagens deles no meu 
documentário. Usamos algumas e criticamos a Rede Globo, no trabalho que estava sendo editado.

Depois, passamos para o texto escrito do funeral, e precisava de alguém para me ajudar, mas a professora novamente não queria interferência de branco e chamou um Bororo da minha aldeia, o professor de Língua Portuguesa, Marcos Borocereu, ele fez a instalação do texto e a narração do vídeo no estúdio da UCDB (Universidade Católica Dom Bosco).

Este foi o primeiro vídeo sobre o funeral bororo, filmado e editado por mim, Boe Ero Kurireu (Grande Tradição Bororo). Fui o primeiro bororo que fez um vídeo de funeral bororo através da minha visão e conhecimento e vou torcer para outros bororos que tenham a mesma vontade, que também façam este tipo de trabalho para conservar a nossa cultura e linguagem, seja da aldeia Meruri, Garças, Tadarimana, Gomes Carneiro, Piebaga ou Perigara.

No meu documentário, gravei os momentos proibidos, mas sei o que estou fazendo, fiz duas versões desse vídeo, uma para as mulheres e crianças não iniciadas e outra completa, que somente os homens podem ver. Sei que a Rede Globo podia ter sido mais criativa, para não mostrar nossos segredos, mas ali não se tratava de criatividade, mas de mostrar o inusitado, o desconhecido, o "fantástico" mesmo. Só que faltou respeito, nada é "fantástico" sem respeito. A falta de respeito mexe com a dignidade da gente e é isto que é duro de aguentar.

O PROARI (Programa de Apoio aos Realizadores Indígenas) da professora Aivone cresceu e ela participou de um projeto com a Faculdade de Comunicação da UFG e a Escola de Cinema de La Paz na Bolívia, Curzo Sien Frontera. Ela tinha 6 vagas para este curso e me incluiu. Foram comigo, dois Xavantes, um Terena e dois Kaiwa-Guaranis. Viajamos juntos com um grupo de estudantes do professor Niltinho, da Comunicação da UFG. O curso foi realizado numa aldeia indígena Condorkinha, do povo Aimara. Produzimos vídeo com um grupo de índios de etnias diferentes. Isto foi muito rico para meus conhecimentos. Depois, o grupo de indígenas desta Escola veio aqui no Brasil e chegou em minha aldeia de Meruri, para a continuação do Curzo Sien Frontera, iniciado na Bolívia

Pouco mais tarde, o mesmo PROARI conseguiu para mim, para Divino Xavante e para Gilmar Terena a cobertura das imagens dos Jogos dos Povos Indígenas, na cidade Paragominas-PA, um encontro de diversas etnias do Brasil. Viajamos e registramos todas as apresentações e as modalidades de esportes, que aconteciam dentro e fora da arena dos jogos. 0 material devia ser editado por mim e por Divino. A cobertura deste evento rendeu para nós um dinheirinho até bom. Foi a primeira vez que ganhei dinheiro fazendo filmagem.

Nesta viagem, conheci outros cinerafistas que haviam participado, como Divino, do projeto Vídeo nas Aldeias. Muitos deles achavam que eu tinha aprendido a filmar nesse projeto e me perguntavam aonde é que aprendi. Eu respondia que aprendi com minha vontade e com a participação e incentivo da minha mu$g a,{ }^{17}$ minha professora de vida, Aivone.

Sem perceber, das alturas dos meus conhecimentos, fui selecionado, junto com Divino, três vezes, para monitorar as oficinas de vídeo que foram realizadas no Museu das Culturas Dom Bosco de Campo Grande - MS; outras duas vezes pelo Vídeo Îndio Brasil, do Cine Cultura, também em Campo Grande - MS; outras duas vezes, com o Divino, na aldeia de Sangradouro com os Xavantes e outras etnias; outro na aldeia Fontoura da etnia Karajá, para a formação de Juanahu Iny Tori, que estava realizando seu primeiro documentário sobre um de seus rituais, uma parceria do recém-criado CEDIPP/ECA, coordenado pelo professor Sérgio Bairon, com o PROARI/MCDB, coordenado pela profa. Aivone e Sérgio Sato. A

17 Muga quer dizer "mãe velha" na nossa língua. 
equipe era composta por mim, Divino Xavante, Juanahu e Caio Lazaneo, um estudante do professor Sérgio Bairon. O documentário dele está rodando por aí, na internet.

Outra vez, foi na adeia Kalapalo no Xingu, para a formação de Kaiautá, filho do cacique, que havia solicitado ao PROARI, uma oficina em sua aldeia, durante o ritual Kuarup. A equipe era composta pela professora Aivone, Sérgio Sato, também fotógrafo da expedição, eu e um cinegrafista italiano, que veio filmar os trabalhos no Museu de Campo Grande, para me ajudar. Foi muito interessante por que ali eles me deram muito valor, teve hora que só eu e Kaiautá podíamos filmar, eu era parente e tinha carta branca.

Só pra ver como o mundo é pequeno. Foi muito interessante porque encontrei ali o fotógrafo que tinha prometido o CD de minhas gravações de canto bororo, no funeral de Macielzinho, o do "Fantástico". Perguntei pelo CD, ele disse que tinha mandado, respondi que eu não tinha recebido, ele disse então que os padres deviam ter roubado, foi saindo de fininho e sumiu no meio daquela multidão de gente.

Enquanto a professora coordenava o Projeto de Reestruturação do Museu das Culturas Dom Bosco, em Campo Grande, ia envolvendo indígenas de todas as etnias que tinham coleção naquele museu. Envolvia a gente na escoIha dos objetos, na limpeza e restauro para a exposição, na produção de vídeo para passar em determinados lugares, dentro das exposições. Para tudo isto ela me chamava. Restaurei os marido imedu e marido aredu, ${ }^{18}$ filmei o ritual de sacralização do espaço da exposição Xavante; ${ }^{19}$ filmei os Bororo retirando os ossos

18 Esses objetos são grandes rodas feitas com talo de buriti, usadas para dançar durante uma representação clânica, antes da exumação do cadáver, no pátio central da aldeia. Representam os dois irmãos, o mais velho e o mais moço, o grande e o pequeno.

19 Os Xavantes dançaram sobre a terra, levada de sua aldeia, e colocada dentro da vitrine no chão, em forma de espiral, para representar o ritual de cura deles. Eu filmei, depois o Divino editou. Tá lá, passando até humanos de antigos Bororo da vitrine do museu velho. Filmei a limpeza deles. Mais tarde, quando o museu novo estava pronto, filmei os Bororo levando esses mesmos objetos sagrados, em cortejo ritual, lá para o Novo Museu; filmei os cantos de preparação e a colocação deles na vitrine, no lugarzinho preparado justo para eles. Depois de muito tempo, filmei a inauguração do museu.

O último trabalho que filmei foi na Rio+20, que fui com a professora Aivone, o Divino, o Juanahu e o Caio Lazaneo, aluno do professor Bairon, o Niltinho da Comunicação da UFG e mais dois de seus alunos, para dar uma oficina para os índios que estavam lá, na Kari Oca, acampamento preparado por Marcos Terena. Quem convidou foi ele. Chegando lá, a coisa não era muito do jeito que a gente pensava, mas conseguimos trabalhar, aproveitei para filmar o cotidiano do acampamento. 0 material está com o Marcos e no CEDIPP/ECA, com o professor Bairon.

Funeral Bororo 2017, Imagens de celular de Paulinho Ecerae Kadojeba
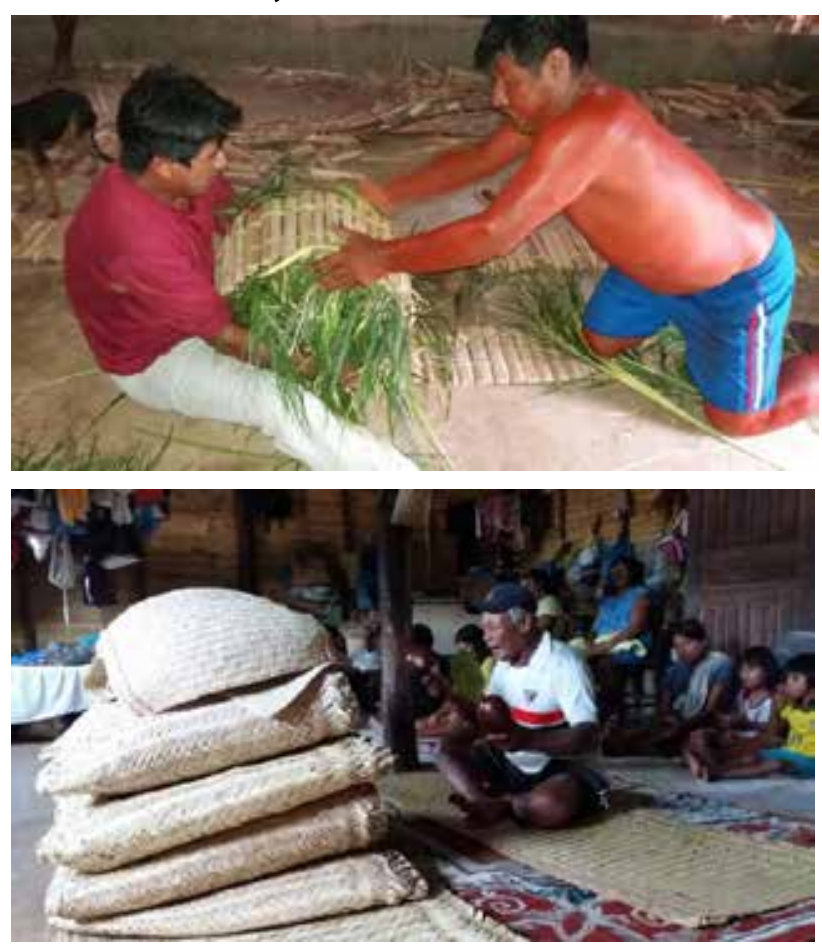

hoje, para quem quiser ver. 
As imagens produzidas pelo próprio indígena são muito diferentes, mais ricas de informações da sua cultua. Além de ter nosso saber e nossos conhecimentos, temos maior abertura com os anciões, quando precisamos saber mais. Nós indígenas gravamos as nossas coisas já sabendo dos detalhes da função que vai acontecer, em determinado ritual. Por outro lado, o registro em imagens e áudio das culturas indígenas, hoje que a juventude não se importa tanto e que os velhos estão morrendo, é a única arma que temos para não deixar nossa cultura morrer. Sem querer criticar, mas o olhar dos não índios para com nossa cultura é totalmente diferente, porque eles registram e comentam do bem entender deles, que nunca é o nosso bem entender.

Acho que, sem perceber, a professora Aivone, quando levou o Divino Xavante para me ajudar no meu documentário Boe Erro Kurireu, ela iniciou não somente um intercâmbio de etnias, mas um "intercâmbio de olhares indígenas", por isto dei este nome ao projeto vivido com ela.

\section{Paulinho e a reconfiguração do Mori}

O conceito de mori na cultura bororo pode ser compreendido a partir do mito da morte de Meri (sol), após a qual Ari (lua), seu irmão menor, sozinho, magrinho e amarelo, andava sem rumo, até que o irmão voltou da morte e levou -o para pescar. Chegando lá, transformou-se em um enorme peixe dourado (Okoge Ekureu), para que o irmão o pescasse e se fartasse com a comida para recuperar a alegria (ALBISETTI; VENTURELLI , 1969, p. 1116)

$\mathrm{Na}$ cultura bororo, "substituições" são muito comuns e podem estar relacionadas ao conceito de "reciprocidade", porque são feitas sempre de modo a criar uma irmandade entre os clãs e as redes de relações que compõem o grande círculo das aldeias bororo, característica fundamental das aldeias ideais. Uma espécie de intercâmbio imediato ou não que vai interferir favoravelmente na manutenção da autonomia do indivíduo e consequentemente do grupo. (CARVALHO, 2006, p. 152).

A palavra Mori, além de recompensa, significa, presente, dádiva, reparação de danos causados ou desagravo, agrado, mimo. (EB I apud CARVALHO, 1994). Na acepção de reparação de danos causados ou desagravo, o Mori corresponde ao felino que é abatido pelo representante do morto, para reparar a morte de um Bororo.

Durante o rico e extenso ciclo fúnebre, algumas pessoas são escolhidas para protagonizar personagens que vão construindo a grande narrativa ritual. o primeiro é o "substituto do morto", que deve ser escolhido dentre os melhores caçadores dos clãs recíprocos. A mãe natural, viva ou morta, é substituída pela "mãe ritual", representada por uma parenta do mesmo clã do finado, cujo marido atua como "pai ritual". Dentre as suas tarefas, esta deve se ocupar do cesto fúnebre. ${ }^{20}$ Cabe ao "substituto do morto", ou aroe maiwu, dançar, ajudar na lavagem e enfeite dos ossos do morto, mas principalmente caçar o felino para presentear a família enlutada, para tirá-la do luto. Do couro da onça é construído um tapete ou esteira com desenhos representativos do clã do morto, doado ao mais velho da família; das garras é construída uma coroa, que é doada ao próprio caçador, durante o ritual de celebração do mori; dos dentes é construído um belíssimo peitoral, que é doado à parenta mais próxima do morto, para que saia do luto e volte a se enfeitar.

Tudo isto vale para o representante do morto o direito de usar nomes e fabricar enfei-

20 Cesto fúnebre ou aroe j'aro, é o cesto no qual são colocados os ossos do morto, depois de enfeitados, para o enterro definitivo. 
tes da outra metade, do clã do finado, direito que the é assegurado por ocasião da entrega do animal. Ao prestar o serviço, o substituto subordina-se a atividades muito duras, razão pela qual são consideradas perigosas para aqueles que delas são incumbidos: cantar por longos períodos, dançar até derramar suor e lágrimas, receber banhos de água fria, ajudar na exumação do corpo, na lavagem dos seus ossos e caçar feras perigosas (VIERTLER apud CARVALHO, 1994).

Como substituto ou representante do morto, ele também terá o compromisso de substituir o morto, nas provisões futuras, para a família enlutada. Em troca ele terá direito a belos enfeites, armas e acesso sexual às mulheres dos clãs recíprocos, que estão prontas para o casamento. Além disto, também terá direito a alimentos preparados pelas mulheres e bebidas ofertadas pelo clã do morto. Isto por toda a sua vida (VIERTLER apud CARVALHO, 1994).

Seja na acepção de substituição ou de reparação de danos, quando Paulinho teve a oportunidade de realizar sua própria produção, encarou-a como uma superação, aliás, também, uma compensação ou reparação do dano causado. Superar ou substituir uma produção na qual teve uma parcela de responsabilidade pela não aprovação dele próprio e de sua comunidade, e compensar esta mesma comunidade pelo dano causado. Dessa forma, Paulinho esperava restabelecer o equilíbrio da aldeia, do mundo dos vivos, abalado pelas imagens sagradas reveladas pelo documentário da Rede Globo. Assim como o funeral bororo restabelece o equilíbrio e a ordem entre o mundo dos vivos e o mundo dos mortos, o mori traz de volta a honra da família, tirando-a do luto, quando o caçador, substituto do morto, entrega os presentes à família enlutada. Paulinho, dentro da lógica de sua cultura, assumiu, consigo mesmo, o compromisso de re- parar a perda cultural. Ali também havia uma espécie de morte.

O longuíssimo ritual para a construção do seu próprio documentário foi o período de "liminaridade" de Paulinho, tal qual a família enlutada à margem da vida da aldeia, esperando pelo Mori que a retirará do luto. A produção do novo documentário, realiza o Mori de Paulinho, substitui o trabalho da Rede Globo que havia causado danos e dor e restabelece a irmandade. Assim como os presentes construídos com as partes da perigosa caça restaura o luto da família, o presente de Paulinho para sua comunidade restaura sua dignidade de Bororo, retira-o de seu próprio luto e devolve o equilíbrio à comunidade. 0 mori de Paulinho marca a liberação da culpa adquirida ao ver revelados os segredos de sua gente; marca a identificação da comunidade com uma nova forma de representação da cultura bororo; marca a aquisição de um novo "status" de Paulinho diante de si mesmo e de sua gente.

\section{Conclusões}

Desde os anos de 1960 que, nos Estados Unidos, antropólogos e documentaristas (Sol Worth e Adair) desenvolvem atividades focalizadas na utilização das tecnologias do som e da imagem pelas populações indígenas. Estas atividades alteram as formas tradicionais de participação na construção de conhecimento e na produção audiovisual. Nesta alteração fundamental, "o olhar indigena que controla as imagens passar-se-ia ao controlo, pela mão, do enquadramento e da montagem. Os meios técnicos passaram para a sua mão. Este método constituía, para os seus autores, uma forma de ensinar, aos que fazem os filmes ou as fotografias, ao pesquisar o significado que atribuem ao seu próprio mundo; reforçava a ideia de começar a estudar o homem como sujeito; contribuía para aprofundar o nosso conhecimento dos papéis heterogéneos 
que as imagens e a comunicação icónica assumem na vida dos homens, e compreender melhor os modelos, culturalmente estruturados, da percepção, da inferência e da expressão" (CHIOZZI apud RIBEIRO, 2001, p. 58). Destas e de outras atividades e consequentes alterações decorre a necessidade de estudo aprofundado das produções audiovisuais indígenas e desenvolver um corpo de conhecimentos, numa perspectiva crítica dos processos criativos e de pesquisa em ação, e a seus questionamentos epistemológicos, éticos, estéticos e políticos.

Carlos Alberto Mattos (2016) refere que, em 1973, durante uma expedição pela Amazônia, o cineasta e indigenista Jean-Pierre Dutilleux e seus guias foram emboscados por guerreiros Txucarramãe, dispostos a matar qualquer homem branco que encontrassem. Dutilleux teria sido poupado porque o cacique Raoni terá reconhecido a câmara, como importante aliado na luta pela sobrevivência da tribo (DUTILLEUX, 1977). Era o início do que alguns autores denominam de "luta mediática". Os habitualmente representados começavam a interessar-se pelas tecnologias audiovisuais e a querer ser eles mesmos a apresentar seus costumes e suas histórias. Monica Frota, a partir 1985, e Vicent Carelli, desde 1987, iniciam uma prática de incentivo à transferência para os indígenas da autoria de seus vídeos. Para isso criaram, como nas histórias acima, contadas por Aivone e Paulinho, oficinas de formação de jovens indígenas. Estas produções, porém, foram, frequentemente, para além da preservação da cultura tradicional e da sua divulgação. Serviram também a objetivos de mediação entre diversas fronteiras - comunicação entre tribos, entre gerações, no conhecimento da cultura, na memória histórica e na identidade causadas pelas agressões: a predação das terras, a violência política, as doenças introduzidas, a expansão dos interesses capitalistas e do tu- rismo e a perda das bases tradicionais de subsistência.

No filme Boe Ero Kurireu - A Grande Tradição Bororo, Paulinho Ecerae Kadojeba, vai além destas práticas, propondo-se a registar um funeral bororo, a partir da sua cultura e dos interditos da sua cultura. Confronta-se com as representações hegemónicas da TV Globo em relação às questões éticas da pesquisa revelação desses interditos, do incumprimento dos compromissos assumidos em relação à população, informações falsas em relação ao funeral bororo, dimensão mercantil, banalizadora, pela integração da reportagem televisiva num programa denominado Fantástico, o show da vida. Falado inicialmente na língua dos bororos (boe wadáru), segue modelos de documentário clássicos (Nanook of the north, de Flaherty, O homem e a câmara de filmar, de Vertov, Chronique d'un éte, de Rouch e Morin, e de muitos outros documentários) ao expor o projeto de realização do filme - "somos nós os bororos que estamos atualmente neste trabalho apresentando uma versão a partir de quem vive na prática a cultura tradicional, a localização cartográfica das aldeias Bororo no Estado de Mato Grosso, Brasil e a apresentação do contexto institucional de produção" Centro de Cultura Padre Rodolfo Lunkenbein de Meruri, com a colaboração de Aivone Carvalho e Sérgio Sato. O filme não se dirige apenas aos bororos, mas assume-se como 0 processo de mediação, alterativo às medias globais, com o público. Para isso, Paulinho explicita que, embora, nos ritos funerários, falem sua língua, um amigo bororo irá explicar o funeral, em português, assumindo assim o processo de mediação com a cultura global do Estado Nação. O filme constitui um processo de reflexividade e um excelente lugar de observação e análise do confronto entre a lógica da reciprocidade da produção e da sociedade indígena - expressa e explicitada, no fil- 
me, pela fala de Muga Mariona "nos (somos) assim, nós pensa tudo parente, pensa todo o mundo (tudo bom?), pensa tudo irmão, pensa tudo filho.... é assim que nós é" - e a lógica mercantil da produção televisiva, subjacente ao programa Fantástico, o show da vida (neste o ritual funerário bororo é tratado como espetáculo) (RIBEIRO, 2016, p. 75-76).

Há, porém, ameaças e novos desafios nas práticas audiovisuais realizadas por cineastas indígenas. Em primeiro lugar, estes não são apenas cinegrafistas, mas cineastas, uma vez que desenvolvem todo o processo criativo de produção audiovisual. Vejamos a definição de cinegrafista: "o profissional responsável pelo manuseio de câmera de filmagem ou vídeo. Em cinema, o operador de câmera é profissional responsável pelo manuseio de câmera de vídeo sob a supervisão de um diretor, como repórter cinematográfico é o profissional responsável pelo manuseio de câmera de vídeo a fim de capturar imagens para serem usadas em reportagens" (wikipedia), ou ainda em guia de profissões e salário (Brasil): "Opera câmera, ajusta foco e ângulo e define composição de quadro para tomar cenas de filmes e espetáculos". Em segundo lugar, torna-se necessário e urgente que controlem a economia, a criatividade, a distribuição e a utilização de suas produções audiovisuais, contribuindo para, como afirma a directora da Special Broadcast Service, na Austrália, "educar o país para a história local, manter a nossa cultura, construir um futuro económico para nós (nossas comunidades) pelo emprego na indústria audiovisual [...] não estamos a assimilar-nos a eles, estamos a tentar promover as nossas diferenças" (RIBEIRO, 2001, p. 64). Além disso, torna-se necessário, segundo Ginsburg, referindo-se aos povos aborígenes da Austrália, um "corpo de teoria e conhecimento crítico sobre as representações e preocupações aborígenes. Os estudos aborígenes, resultado de um espaço de produção discursiva em antropologia e estudos culturais nos fins dos anos oitenta, transcenderam o essencialismo estático da disputa entre a conservação e preservação e a divulgação, desafiando com a cultura na política da 'aldeia global'. Nestes trabalhos reconhece-se que "a identidade aborígene e a identidade étnica não devem ser equacionadas no domínio despolitizado do multiculturalismo: que a etnicidade é qualquer coisa reinventada e reinterpretada em cada geração; que a procura ou a luta por um sentido de identidade étnica é a (re)invenção e a descoberta de uma visão ética orientada para o futuro; que a busca de coerência está enraizada numa conexão com o passado, o sentido abstraído do passado - um importante critério de coerência -, é um trabalho (coisa que pode ser trabalhada, praticável) ético para o futuro; que este trabalho é um meio (instrumento) da invenção cultural que refracta e recombina elementos das sociedades dominante e minoritária" (GINSBURG, 1995, p. 282 apud RIBEIRO, 2001, p. 64).

Carlos Alberto Mattos (2016, p. 45) alerta para "algumas complexas questões" e ameaças em relação às produções indígenas: "será possivel evitar que o envolvimento dos índios com a produção tecnológica conduza à reprodução de esquemas viciados de representação televisiva? Como garantir que os padrões de ritmo tecnológico e a estética desses trabalhos não se choquem com as formas tradicionais de expressão indígena?"

Conheci o filme Boe Ero Kurireu - A Grande Tradição Bororo, de Paulinho, há alguns anos, usei-o em alguns eventos e em pulbicações. Conheci também, há alguns anos, as histórias acima contadas pelos dois autores principais do texto, bem como o Museu de Culturas Dom Bosco. Acompanhei também os projetos de pesquisa de Sérgio Bairon, durante mais de uma década. Em 2016, reencontrei de novo Aivone Carvalho e, através dela, Paulinho Ecerae 
Kadojeba e Divino Tserewahú Tsereptse. Pelas conversas mantidas, as questões enunciadas são comuns aos autores do texto e a projetos

\section{Referências}

ALBISETTI, C.; VENTULLE, A. J. Enciclopédia Bororo. Campo Grande: UCDB, 1962, 1969, 1976 e 2003. V. I, II, III e IV.

CARVALHO, Aivone. 0 museu na aldeia - Comunicação e Transculturalismo no diálogo museu e aldeia. Campo Grande: UCDB, 2006.

Tempo de Aroe: simbolismo e narratividade no funeral bororo. 1994. 200 f. Dissertação (Mestrado em Comunicação e Semiótica) - Programa de Pós Graduação em Comunicação e Semiótica.Pontifícia Universidade de São Paulo, São Paulo, 1994.

COLBACCHINI, A.; ALBISETTE, C. Os Bororo orientais, orarimogodoge do planalto oriental do Mato Groso. Rio de Janeiro: Companhia Editora Nacional, 1942.

DUTILLEUX, Jean-Pierre Tribus: les peuples premiers, Paris: Vilo, 2013

LÉVI-STRAUSS, C. Tristes trópicos. Tradução de Jorge C. Pereira. Lisboa: Edições 70, 1986.

RIBEIRO, Berta. O "Indio Brasileiro: Homo Faber e Homo Ludens". In A Itália e o Brasil indígena. Rio de Janeiro: Index Editora,1983. p. 13-23

RIBEIRO, José da Silva; COLÁ S. Jon. Oh Que Sabe! As imagens, as palavras ditas e a escrita de uma experiência ritual e social. Porto: Edições Afrontamento, 2001.

RIBEIRO, José da Silva. A comunidade face aos poderes: resistência e reflexividade social. Cinema e Território, n. 1, p. 58-75, 2016. Disponível em: <http://www.ct-review.org/wp-content/uploads/2016/04/6-JOS\%C3\%89-RIBEIRO-58-78.pdf>.

MATTOS, Carlos Alberto, "Índio quer Câmara" em Cinema de fato: anotações sobre o documentário. Rio de Janeiro: Jaguatirica, 2016. p. 43-45. de desenvolvimento de Produções Audiovisuais Indigenas e também de Etnografias Audiovisuais Participativas.

SATO, S. H. O. A tensão dialógica entre auto e heterorrepresentação no funeral bororo na terra indígena de Meruri. 2009. 323 f. Dissertação (Mestrado em Comunicação e Semiótica) - Programa de PósGraduação em Comunicação e Semiótica, Pontificia Universidade Católica de São Paulo, São Paulo, 2009.

SCHADEN, E. Mitologia heróica de tribos indígenas do Brasil. São Paulo: EDUSP,1989.

TURNER, Victor. 0 processo ritual. Petrópolis, RJ: Vozes, 1974.

VIERTLER Renate. Aroe J'Aro - Implicações adaptativas das crenças e práticas funerárias dos bororo do Brasil Central. 1982. 647 f. Tese (Livre Docência em Antropologia) - Faculdade de Filosofia, Letras e Ciências Humanas, Universidade de São Paulo, São Paulo, 1982.

\section{Filmografia}

BOE, Ero Kurireu. A Grande Tradição Bororo. Direção: Ecerae Kadojeba, Paulinho. Produção: PROARI. Documentário. Disponivel em: 2005.

BOE, Ero Kurireu. A Grande Tradição Bororo. SATO, S. H. O. Ipermídia, Disponível em: Dissertação de Mestrado PUC, São Paulo: 2009

SEPULTAMENTO da tribo bororo é uma Janela para a pré-história. Direção: Maria Luiza Silveira. Produção: TV Centro América / Rede Globo. Documentário. 2003.

KARI-Oka Rio + 20 Direção: Divino Tserewahu e Paulinho Kadojeba. Produção: CEDIPP/ECA. Curta Metragem. Disponivel em: CEDIPP/ECA

DUTILLEUX, Jean-Pierre, Raoni, SND. Groupe M6, 1977. Fragmentos e https://www.youtube.com/watch?v=eNEvbYJR7Sw 
Produções da "oficina multiétinica", Aldeia de Sangradouro, 2011. Coordenação: Caio Lazaneo, Divino Tserewahu e Paulinho Ecerae Kadojeba.

DATSA - Alimentação. Direção: Grupo I (composto de 3 Xavante e 2 kalapalo) Produção: CEDIPP/ECA/ USP, PROARI / MCDB Disponível no CEDIPP/ECA/USP

ROPRÚ Boegigudu - Poluição - Direção: Grupo II (composto de 3 Bororo e 2 Xavante) Produção: CEDIPP/ECA/USP, PROARI / MCDB Disponivel no CEDIPP/ ECA/USP

DAHODZÉ - Saúde. Direção: Grupo III (composto de 5 Xavante, 1 Kuikuro e 1 Bororo) Produção: CEDIPP/ ECA/USP , PROARI / MCDB. Disponivel no CEDIPP/ ECA/USP

A'UWEN himiromhuri - Artesanatos Xavante. Direção: Grupo IV (composto de 3 Xavantes e 2 Bororos) Produção: CEDIPP/ECA/USP. Disponivel em: BERAHATXI-RBI Olodu Mahadú - Povo que veio do fundo do rio. Direção: Juanahu Iny Tori Produção: CEDIPP/ECA/USP.

Produções da oficina "Produção Partilhada do Co- nhecimento", Sangradouro/ECA/ USP, 2013. Coordenação: Aivone Carvalho, Sergio Bairon e Divino Tserewahu.

JARUDORI. Aldeia Bororo. Direção: Paulinho Ecerae Kadojeba e grupo. Produção: CEDIPP/ECA/USP. Disponivel no CEDIPP/ECA/USP.

DIABETES - Direcão: Pascoalino Tseremadzawe e grupo. Produção CEDIPP/ECA/USP. Disponível no CEDIPP/ECA/USP.

ALCOOLISMO - Direcão: Natal Awhaho'a e grupo. Produção CEDIPP/ECA/USP. Disponível no CEDIPP/ ECA/USP.

MUSEU e Memória Direcão: Agostinho Eibajiwu e grupo. Produção CEDIPP/ECA/USP. Disponivel no CEDIPP/ECA/USP.

MEIO Ambiente. Direcão: José Marinini Tsopre tsowa'o e grupo. Produção CEDIPP/ECA/USP. Disponivel no CEDIPP/ECA/USP.

Recebido em: 10.01.2017

Aprovado em: 03.04.2017

Paulinho Ecerae Kadojeba é cinegrafista Bororo, realizador/diretor do filme, BOE, Ero Kurireu. A Grande Tradição Bororo, inciou em 2017 uma pesquisa sistemática do funeral Borro utilizando smartphone. Nasceu na Reserva de Gomes Carneiro, na aldeia de Córrego Grande. Estudou na aldeia de Meruri até concluir o segundo grau. Participou de diversas oficinas de formação de cineastas indígenas, tendo atuado mais tarde em outras como formador. Registrou inúmeros rituais em sua comunidade.e-mail: eceraekadojeba@hotmail.com

Aivone Carvalho é pós-doutoranda do Programa de Pós-graduação em Arte e Cultura Visual da Universidade Federal de Goiás supervisionado pelo professor José da Silva Ribeiro. Doutora em Comunicação e Semiótica pela Pontificia Universidade Católica de São Paulo (2003), com pós-doutorado em Ciências da Comunicação pela Escola de Comunicação e Artes da Universidade de São Paulo (2015). Desenvolveu estudos na área de museologia na Itália. Criou junto aos Bororo e Xavante seus Museus Comunitátios. Idealizou e coordenou o Projeto de Reestruturação do Museu das Culturas Dom Bosco. e-mail: carvalhoaivone@gmail.com

Universidade Federal de Goiás (UFG). Campus Samambaia. Caixa Postal 131 - 74.001-970 - Goiânia (GO) - Brasil. Secretaria: Telefax (62) 3521-1440

José da Silva Ribeiro é pesquisador e professor visitante dos programas de Pós-graduação em Arte e Cultura Visual e Antropologia Social da Universidade Federal de Goiás. Foi professor da Universidade Aberta de Portugal. Coordena o grupo de pesquisa Media e mediações culturais do Centro de Estudos das Migrações e das Relações Interculturais da Universidade Aberta de Portugal. e-mail: jsribeiro.49@gmail.com

Rua R8, Setor Oeste, Caixa Postal 74125-130, Goiânia (GO), cel 62981255485 